\title{
PECULIARITIES OF STRUCTURAL CHANGES IN THE MACHINE-BUILDING INDUSTRY OF UZBEKISTAN
}

\author{
Khaydarov Khayrulla Gulamovich \\ Independent researcher of Tashkent State University of Economics, Tashkent, Republic of \\ Uzbekistan
}

Article DOI: https://doi.org/10.36713/epra3871

\begin{abstract}
The article describes the specific methods and mechanisms of structural change in the mutually beneficial structure of machine-building enterprises of Uzbekistan, the provision of raw materials, the improvement of production of selected and new types of products.
\end{abstract}

KEY WORDS: competitiveness, modernization, diversification, stock market, marketing, modification, lender, assets, stocks, financial resources, investment, infrastructure.

\section{INTRODUCTION}

One of the main and most important principles in the effective implementation of structural changes in the economy is to take into account the specific characteristics of each sector. The role and importance of the industry in the national and foreign economy, its level of development, the characteristics of economic resources and other factors require the development and application of specific methods and tools, solutions and conclusions, mechanisms and supports of structural change. The Decree of the President of the Republic of Uzbekistan dated February 7, 2017 "On the Strategy of actions for further development of the Republic of Uzbekistan", which sets priorities for economic development and liberalization [1]. Enhancing the competitiveness of the economy through the deepening of structural changes, stimulating the localization of production, first of all, replacing the import of consumer goods and components, expanding the intersectoral industrial corporation are among the most important tasks.

\section{METHODS}

Research aimed at strengthening cooperation in industries and sectors through modernization and diversification of the economy, targeted use of factors that increase the competitiveness of enterprises in domestic and foreign markets, increase the efficiency of production and technical factors economists T.Ziyoev, Sh.Israilova [2], Studied by M.Sharifkhodjaev, Yo.Abdullaev [3]. Extensive research on the scientific and theoretical basis and specifics of the development and competitiveness of sectors of the economy was conducted by foreign economists - V. Biryukova, A. Akhtulova [4], N. Sayfulin [5].

\section{RESULTS AND DISCUSSIONS}

It requires the introduction and effective implementation of a specific mechanism for assessing the methods and economic situation of structural changes in the engineering industry of Uzbekistan. In this regard, it is expedient to identify the existing shortcomings in the period of restructuring of the network, their causes and areas for solution (Table 1). 


\section{EPRA International Journal of Research and Development (IJRD) \\ Volume: 5 | Issue: 7 | July 2020 \\ - Peer Reviewed Journal}

Table 1. Existing problems, shortcomings and directions for their solution in the restructuring of the engineering network

\begin{tabular}{|c|c|c|c|}
\hline № & $\begin{array}{c}\text { Content of } \\
\text { problems and } \\
\text { shortcomings }\end{array}$ & Reason of origin & Solution directions \\
\hline 1 & $\begin{array}{l}\text { Inadequacy of means } \\
\text { of production in the } \\
\text { industry }\end{array}$ & $\begin{array}{l}\text { Business entity } \\
\text { technical } \\
\text { the structure is } \\
\text { unreasonable }\end{array}$ & $\begin{array}{c}\text { In terms of production at each enterprise in the } \\
\text { industry: } \\
\text { - means of production } \\
\text { grouping; } \\
\text { - lease or sale of unusable; } \\
\text {-purchase of necessary equipment. }\end{array}$ \\
\hline 2 & $\begin{array}{l}\text { Lack of financial } \\
\text { resources }\end{array}$ & $\begin{array}{c}\text { Improper } \\
\text { organization of } \\
\text { production and sale of } \\
\text { the product }\end{array}$ & $\begin{array}{l}\text {-ensure the involvement of the industry's own } \\
\text { funds in the necessary tasks in the plan of } \\
\text { structural changes; } \\
\text { - Document on providing financial resources for } \\
\text { structural changes. This document is necessary for } \\
\text { communication with organizations involved in } \\
\text { lending. }\end{array}$ \\
\hline 3 & $\begin{array}{c}\text { Lack of staff to } \\
\text { implement } \\
\text { structural changes }\end{array}$ & $\begin{array}{l}\text { Experienced in the } \\
\text { network } \\
\text { and there is an } \\
\text { indifference to } \\
\text { professional training }\end{array}$ & $\begin{array}{l}\text {-involvement of qualified specialists in structural } \\
\text { change (marketing, finance); } \\
\text {-ensure that employees have experience in } \\
\text { structural changes, training, etc. }\end{array}$ \\
\hline 4 & $\begin{array}{l}\text { Dependence of joint- } \\
\text { stock companies on } \\
\text { the stock market }\end{array}$ & $\begin{array}{l}\text { Requires a large } \\
\text { amount of money }\end{array}$ & $\begin{array}{c}\text {-increase the efficiency of targeted direct } \\
\text { investment. }\end{array}$ \\
\hline
\end{tabular}

As can be seen from the table above, the main shortcomings in the implementation of structural changes in the industry remain due to negative factors such as obsolescence of means of production $(63.9 \%)$ [6], lack of funding and lack of qualified personnel. However, as a result of the effective implementation of structural changes, we can achieve the following positive features (Table 2). 


\section{EPRA International Journal of Research and Development (IJRD)

Table 2. Making structural changes in the engineering industry positive directions of increase

\begin{tabular}{|c|c|c|}
\hline № & $\begin{array}{l}\text { The content of the positive } \\
\text { aspects }\end{array}$ & Objectives to be achieved \\
\hline 1. & $\begin{array}{l}\text { Provides property reform and } \\
\text { production restructuring during } \\
\text { the period of sector } \\
\text { restructuring and privatization }\end{array}$ & $\begin{array}{l}\text {-formation of a layer of real owners in the enterprises of the } \\
\text { industry; } \\
\text { - formation of a competitive environment; } \\
\text { - specialization of the industry in the production of components } \\
\text { and finished products; } \\
\text {-organization of effective production activities on successful } \\
\text { structural changes in the economy. }\end{array}$ \\
\hline 2. & $\begin{array}{l}\text { The network is constantly being } \\
\text { reformed and moved to a new } \\
\text { level in terms of quality }\end{array}$ & $\begin{array}{l}\text { - Efficient use of production capacity and raw material } \\
\text { resources will be established; } \\
\text { - Intensive development of production and adaptability to } \\
\text { market conditions; } \\
\text { - balanced conditions of supply and demand; } \\
\text { - Increased independence in the free choice of production and } \\
\text { pricing. }\end{array}$ \\
\hline 3. & $\begin{array}{l}\text { Structural changes include } \\
\text { changes in the production } \\
\text { program and innovations in } \\
\text { related structures }\end{array}$ & $\begin{array}{l}\text { - reorganization of the technical base of the network; } \\
\text { - performs the function of social and labor distribution; } \\
\text {-experienced and qualified staff is formed; } \\
\text {-Involvement of financial (active and passive) funds in targeted } \\
\text { plans and control over it will be strengthened. }\end{array}$ \\
\hline 4. & $\begin{array}{l}\text { It is possible to perform } \\
\text { strategically practical tasks in } \\
\text { the network }\end{array}$ & $\begin{array}{l}\text { - Agreements are made with partners in the country and } \\
\text { abroad; } \\
\text {-coordinates activities with structural units and subcontractors; } \\
\text { - decision-making on joint ventures and the design and } \\
\text { development of autonomous production units operating in the } \\
\text { industry. }\end{array}$ \\
\hline
\end{tabular}

It is known that the enterprises of the machine-building industry of the Republic did not specialize in the production of components, and all the necessary parts were imported. As a result, the share of machinery and equipment in imports increased (CIS countries to $15.9 \%$, other foreign countries to $58.8 \%$ ) [7], the efficiency of the industry and development prospects remained dependent on foreign manufacturers. Accordingly, it is clear that today a large amount of money is required to restructure the machine-building industry, that is, to produce modern finished products, to attract equipment and technology. To do this, one of the most convenient ways of structural change is to improve the efficient use of internal resources of the network.

Overcoming the existing financial difficulties in the above-mentioned sector requires the application of well-designed and prompt measures. Because, first of all, it is necessary to improve the overall condition of the network through urgent measures, to improve the attitude of workers and other employees to production, the attitude of other industry towards this industry. This will ensure the reliability of the network to attract foreign investment. Second, the introduction of a production project based on capital investments that will ensure the future of the industry will be achieved.

In the implementation of effective production projects, it is necessary to pay attention to the affiliation, diversification and ownership of activities. This, in turn, requires an assessment of the following priorities in the structure of the network:

- Grouping of types of products that do not meet the requirements of the world and national markets;

-improve the introduction of selected and new types of products;

- redistribution of equipment required for production and experienced managers, consultants, qualified personnel;

- It is necessary to improve the market-based management mechanism.

Structural changes in the industry depend in many respects on the composition and regional location of production. At the same time, it is important to eliminate regional disparities in production, mainly in the enterprises of the sector. First of all, based on the mutually acceptable structure of enterprises, the availability of raw materials and the development of priority areas of production in places where demand is high, the 


\section{SJIF Impact Factor: 7.001| ISI I.F.Value:1.241| Journal DOI: 10.36713/epra2016 ISSN: 2455-7838(Online) \\ EPRA International Journal of Research and Development (IJRD) \\ Volume: 5 | Issue: 7 | July 2020 \\ - Peer Reviewed Journal}

following tasks need to be addressed based on the economic potential and social characteristics of the region. These are:

- re-evaluation of the development of raw materials processing industries in the region; enterprises;

- organization of additional production

- Ensuring the structure of labor resources in the regions, employment and integration of labor resources.

- However, the enterprises of the machinebuilding industry are not optimally located in the country today. It is an important solution to maintain the production of homogeneous products such as technical parts, spare parts, restoration of details of light industry, which are available in the regions, in the regions where they are most needed.

- In order to further improve the regional status of structural changes, it is necessary to organize new economic cooperation between large and medium-sized enterprises, based on objective market conditions. At the same time, the interaction of large and medium-sized enterprises with large enterprises should be based on the orders of large manufacturers. Because, first of all, it focuses on the production of consumer goods by small and medium enterprises. Second, the mutual integration of enterprises will deepen and regional economic cooperation can be ensured.

- It would be more appropriate if it is based on the stages of structural change, the initial stage of which includes measures to assess and improve the financial situation, marketing services, compliance of the administrative structure, market mechanism and elimination of weaknesses.

- In the process of structural change in enterprises, it is necessary to make an operational assessment of its market position, financial and economic activity and management efficiency.

- When assessing the market position of the enterprise, the following should be considered.

a) determine the position of the enterprise in the market by obtaining and analyzing the following information: On the indicators of economic development of industries and regions, the directions of state policy, which determines the production and sale of products and raw materials consumed by the enterprise;

- On the current level of production in the country, the volume of imports and exports of products and raw materials, as well as the volume of production of import-substituting products;
- about consumer and market
segmentation;
- about the main classifications of the market for each segment (price elasticity of the resulting price, the potential and real capacity of the market, its saturation with products and goods); export markets;

- Geographical distribution of goods,

b) identification of competitors and analysis of their activities:

- general information about competitors (sales volume in the market as a whole and its segments, total market share, goals, market behavior, self-assessment, etc.);

- Strengths and weaknesses of competitors (product quality, pricing policy, movement of goods, sales policy, after-sales service, forms of live settlements, prepayment, extension of payment, etc.) ;

- Determining the level of competition of manufactured products in the commodity sector (pressure through substitute products, the ability of buyers and suppliers to come to an agreement).

c) to make optimistic, pessimistic and moderately limited forecasts of market development based on the results of marketing research, within each of which the following is recommended:

- determine the phases and duration of the life cycle for each type of product; enterprise.

- assessment of potential risks of the

The following indicators are taken into account when evaluating the management of the enterprise: environment.

1. Attitudes towards changes in the business

a) Is the problem the result of a change in the external situation or the result of a decrease in the overall work rate?

b) Did management identify change quickly or did they expect shortages to occur?

c) Does management have a clear, efficient and reliable strategy for solving problems?

d) Is a unified approach to the problems within the management structure clear?

e) Does the enterprise have the political power to influence the external factors of the problem?

2. Ability to control the enterprise.

a) Does the enterprise have a clearly defined business plan?

b) Does the enterprise have adequate financial control?

c) Does the enterprise have an adequate management function? 


\section{SJIF Impact Factor: 7.001| ISI I.F.Value:1.241| Journal DOI: 10.36713/epra2016 ISSN: 2455-7838(Online) \\ EPRA International Journal of Research and Development (IJRD)

d) Is the enterprise doing any work to confirm that the workforce meets the requirements of the action?

e) Is the cash flow that is effective during the management period of the enterprise considered?

3 . The ability to manage to get out of a crisis.

a) Can management clearly identify problems and take responsibility for solving them?

b) Is management capable of developing a realistic and effective recovery plan?

c) Is management able to repay the loan and support creditors?

d) The clarity of the entrepreneurial spirit and the existence of a clear path to recovery?

e) Does the management have the necessary technical skills, or are there significant interruptions in it?

When evaluating this process logically, the poor financial condition of the industry automatically requires a positive approach to it. To do this:

1) By redistribution of internal resources of the enterprise:

- Cash flow management;

- Cost reduction by identifying and preventing excessive costs and losses;

- Improving the expansion of the range of additional products in the revision of the list of product names;

2) Through property restructuring:

- Liquidation of unused assets and directing to the sale of inefficient fixed assets;

- Modification of production operations in order to reduce the temporary norms for the production shift of product parts. At the same time, the activities of economically insolvent enterprises and efficient enterprises should be changed in the following order.

Great attention should be paid to financial change in economically insolvent enterprises. Although the state rehabilitation program has been implemented and benefits have been provided to these enterprises, there is an inability to produce products. But it is difficult for lenders to operate without a reliable production plan, i.e. to lend money to enterprises undergoing structural change. To this end, it is advisable to implement a strategy option in a situation of structural change deficit. At the same time, it is necessary to strengthen control over the projected cash flows, interest rates (use of a single rate to determine the current value of investments). As a result, the interest rate charged should be the real value of the investment made in the investment.

In economically insolvent enterprises, a convenient method is to assess business value. In this regard, special attention should be paid to joint-stock companies. To do this, it is necessary to strengthen product sales and advertising. The following options for financial change may yield the expected results. That is, the ratio of the value of private capital to debt. In the period of structural change, it is necessary not to reduce the current production, to involve the enterprise in the target plans of the industry by collecting receivables.

The reduction of production volumes during the period of structural changes can lead to negative consequences, firstly, a sharp decline in financial revenues in the industry, and secondly, the incomplete satisfaction of demand for the product in the country. To do this, it is advisable to continue production in the network in the following groups:

Mass production is defined by the division of the industry into a system of agriculture, consumer goods, industry and enterprises, associated with the production of a large volume of necessary products. In this case, the same labor operations are performed by a large number of workers. The advantage of mass production is that every technological operation performed is carried out using previously used equipment. In this case, the coefficient of action $\kappa_{b a}=1$ were marked.

Single production - specializes in the production, processing and repair of small parts. Provides a package of private and public orders. In this case, the next product may differ from the previous product. Through this method of production, the creation of products for the export of the industry can also be widely implemented. That is, the addition of mass and multiple production methods, as well as the implementation of production based on orders, will have a major impact on the growth and efficiency of network production. In turn, ensures the production of newly designed products and parts based on the scientific and technical process.

Numerous production-preparation and repair are characterized by recyclable products. The importance of determining the quantity of products produced will depend on the coefficient of action performed on a large number of different, medium and small-scale production. This process is very important during production, i.e. it can prevent overproduction and waste. Will be in constant contact with mass and single production teams in the implementation of production.

The amount of work performed in largescale production during this period $1<\mathrm{Kb} a<10$,

For the production of a large number of medium $10<\mathrm{Kb}$ a $<20$,

For the production of small numbers $20<$ $\mathrm{Kba}<40$ equal.

These normative indicators prevent inappropriate consumption of raw materials. In our opinion, it is necessary to study the investment market, strengthen the activities of joint ventures and 


\section{SJIF Impact Factor: 7.001| ISI I.F.Value:1.241| Journal DOI: 10.36713/epra2016 \\ ISSN: 2455-7838(Online) \\ EPRA International Journal of Research and Development (IJRD)

introduce a network design and engineering center in the country.

In the restructuring of the industry, it is necessary to pay special attention to the development of relations of large enterprises with small businesses and private entrepreneurship. That is, specialization through the transfer of certain parts of production to small and medium enterprises, it is expedient to use the benefits of inter-farm integration processes. Also, the transfer of some parts of production to small and medium-sized enterprises will reduce the cost of production, provide tax benefits. In addition, small and medium-sized enterprises are quick to adapt to the market and have the ability to meet them quickly by studying the needs of customers. It is expedient to establish relations with small and medium enterprises, first of all, in large enterprises of the industry. In addition, some enterprises in the industry are formed in the form of joint-stock companies, despite the small scale of production. It is known that joint-stock companies are the preferred form of fullfledged opportunities for large enterprises in terms of organizational and legal relations, because their management is relatively complex and its costs are high (for example, issuing shares, publishing information on shares, etc.). Therefore, mediumsized enterprises established in the form of jointstock companies should be transformed into more limited liability companies. This is due to the fact that the industry is not flexible due to the fact that enterprises are accustomed to the production of products in large categories and in a variety of ways.

\section{CONCLUSION}

By defining the specifics of the structural changes taking place in the machine-building industry, the role of the machine-building industry in the structure of the national economy will be increased. In order to achieve positions in domestic and foreign markets, methodological support will be provided to the network, overcoming internal infrastructure and resource constraints, and maintaining a balance between economic and social goals.

\section{REFERENCES}

1. Decree of the President of the Republic of Uzbekistan dated February 7, 2017 No PD4947 "On the strategy of further development of the Republic of Uzbekistan". www: Lex.uz

2. T.Ziyoev, Sh.Israilova. Theory of industry and enterprise economics. Textbook.-T: TSU. 2011.

3. M.Sharifkhojaev, Yo.Abdullaev. Theory and practice of market economy.-T: Ukituvchi, 2000.
4. V. Biryukova, A. Akhtulova. Competitiveness of the Russian economy (theory, practice, trajectory of changes and ways to increase). Textbook / Under the general. ed.-Omsk: Publishing house of SibADI, 2005.

5. N. Saifulin. Competitiveness: theory and methodology / Monograph.-Kazan. Center for Innovative Technology. 2008.

6. Data of the Statistics Committee of the Republic of Uzbekistan. *)By IFUT-2 classifier 25,26,27,28,29,30,33 activities. 2019.

7. Annual statistical collection of the Republic of Uzbekistan - T: 2019. Page 253. 